\title{
Cliff retreat and talus development at the caldera wall of Mount St. Helens: Computer simulation using a mathematical model
}

\section{Hiroyuki Obanawa $^{\mathrm{a},}$ and Yukinori Matsukura ${ }^{\mathrm{a}}$}

aGraduate School of Life and Environmental Sciences, University of Tsukuba, Tenno-dai 1-1-1, Tsukuba, Ibaraki 305-8572, Japan

\begin{abstract}
To simulate the landform evolution at the caldera wall of Mount St. Helens, USA, a mathematical model for talus development was applied to model the topographic change during the 11years from the volcanic eruption, i.e., from formation of the cliff. Simulated results show that the topographic change is predicted to be large for about 10years after the eruption and to decline thereafter. If snow accumulation in the talus slope deposits is negligible, the talus top will not reach the cliff top within 300years after the eruption. Talus growth in Mount St. Helens was much faster than that in the Chichibu Basin, Japan. This may indicate the low strength and/or high weathering rate of the rockwall of Mount St. Helens, resulting in rapid production of debris and rapid retreat of the cliff.
\end{abstract}

Keywords: Talus; Cliff; St. Helens; Mathematical model; Computer simulation

\section{Introduction}

Many studies have been made of talus landforms. Geomorphologic processes on a talus slope have been examined by various authors (e.g. [Kirkby and Statham, 1975], [Pérez, 1988], [Pérez, 1993], [Kotarba, 1997], [Bertran and Texier, 1999], [Decaulne and Saemundsson, 2006] and [Sass and Krautblatter, 2007]). The inclination of talus slopes and the stability of a slope composed of granular materials have been studied in detail (e.g. [Chandler, 1973], [Statham, 1976], [Carson, 1977] and [Onda and Matsukura, 1997]). Also, the deposition rate of talus slopes has been investigated (e.g. [Mills, 1992], [Hétu and Gray, 2000], [Sass and Wollny, 2001] and [Curry and Morris, 2004]).

As well as these studies based on field surveys and laboratory experiments, mathematical models have been proposed for talus development ([Lehmann, 1933], [Bakker and Le Heux, 1947], [Scheidegger, 1961], [Scheidegger, 1962], [Caine, 1969], [Hutchinson, 1998] and [Hutchinson and Stuart, 2003]). These models have several defects. They are unable to 
separate the rate of retreat of a cliff into two components corresponding to the rates of parallel retreat and declining retreat, so that they cannot describe topographic change involving both types of retreat. To overcome this problem, Obanawa and Matsukura (2006) proposed a new mathematical model for talus development and retreat of a cliff behind the talus, which can deal with the rates of declining cliff retreat and parallel retreat independently. This allows better modeling of changes in talus topography. The present study applies this model to a real talus landform at the caldera wall of Mount St. Helens, Washington, USA. The rates of cliff retreat are calculated in detail, separating the declining and parallel retreat components. We then predict the future topographic change of the talus using the calculated rates of retreat.

\section{Mathematical model for talus development}

\subsection{Definition of geomorphological terms}

The terms used to describe talus landforms are shown in Fig. 1. "Talus" or "talus slope" refers to the surface of the talus sediment, and "cliff" or "cliff face" to the steep slope behind the talus. The cliff top is bordered by an "upper slope" and the foot of the talus slope is bordered by a "lower slope". "Retreat of the cliff" refers to the topographic change by which the cliff face migrates backward with time (toward the right of Fig. 1) due to erosional processes on the cliff, such as rockfalls.

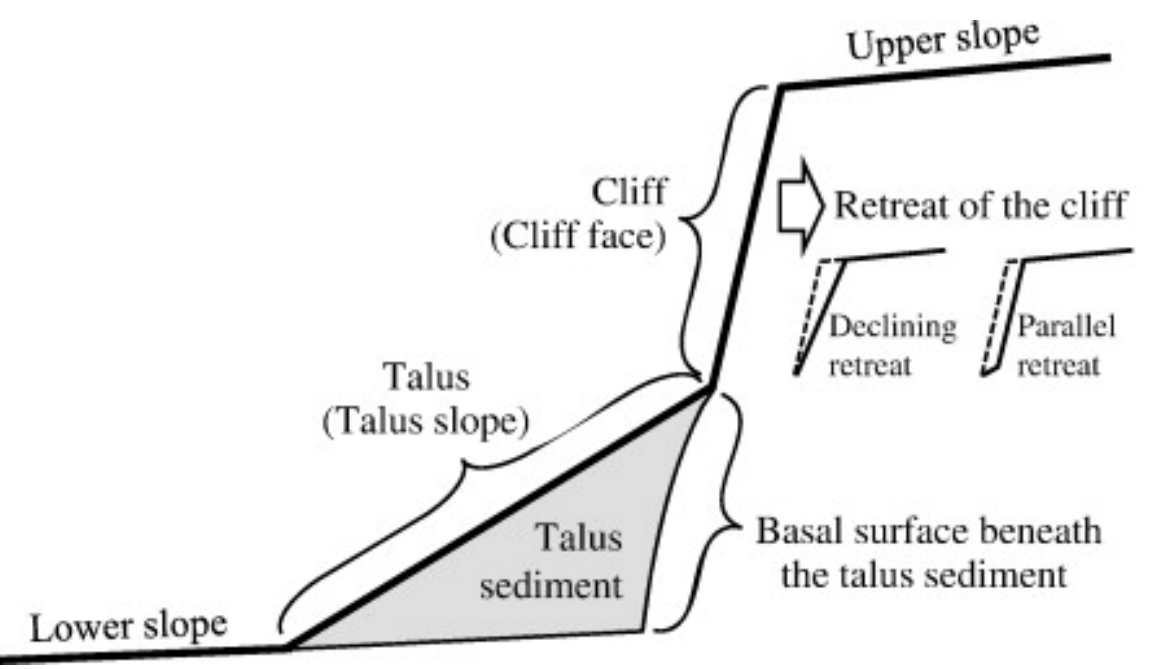

Fig. 1. Definition of geomorphologic terms on talus.

There are two types of slope retreat: with declining angle and at a constant angle. The first is defined here as "declining retreat" and the second as "parallel retreat". The rates of 
topographic change due to these two modes of retreat are called the "rate of declining retreat" and "rate of parallel retreat".

\subsection{Definition of symbols}

Obanawa and Matsukura (2006) have proposed a mathematical model for the topographic change of a cross section of a talus landform, based on the material balance between the volumes of erosion and deposition. The model is based on equations relating to topographic forms and the rates of topographic change. Fig. 2 shows the modeled infinitesimal topographic change due to cliff erosion and talus deposition during the unit time $\Delta t$, from stage $n-1$ to stage $n$ (topographic changes are exaggerated). This topographic change is iterated and the talus development is calculated successively in the model.

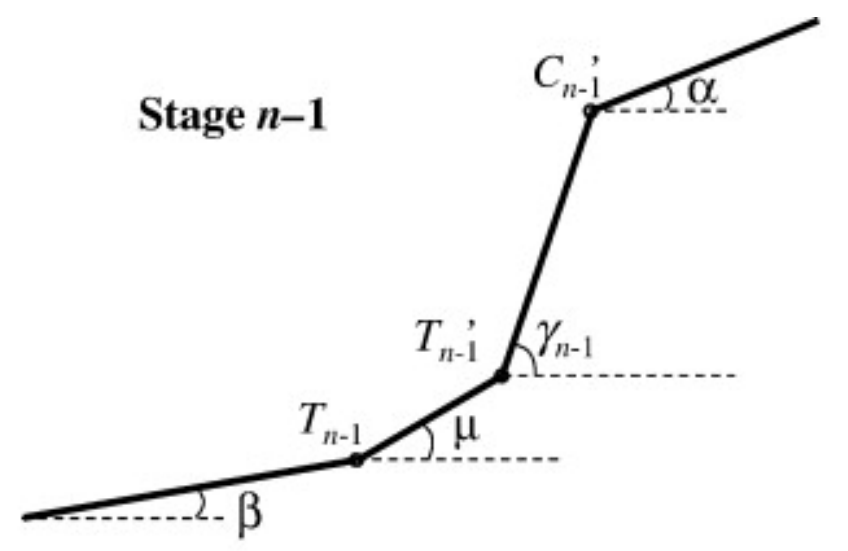

\section{$\Delta t$}

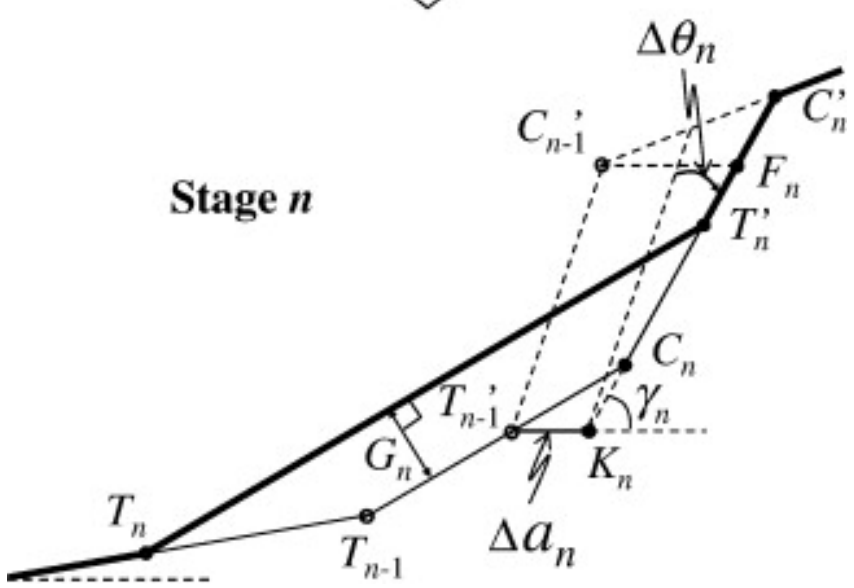

Fig. 2. Infinitesimal change due to cliff erosion and talus deposition. 
We define symbols as follows: $T_{n}$ is the talus toe, $T_{n}{ }^{\prime}$ is the talus top, and $C_{n}{ }^{\prime}$ is the cliff top. Subscript $n$ denotes the number of the stage (i.e., time). The angles $*, \gamma_{n}, \mu$ and $\beta$ respectively denote the angles of the upper slope, cliff face, talus slope, and lower slope. The three angles $*, \mu$ and $\beta$ are constant and do not vary with $n$. The distance $\Delta a_{n}$ and the angle $\Delta \theta_{n}$ respectively denote the parallel-retreat distance and the declining-retreat angle of the cliff between stage $n-1$ and stage $n$. The quantity $v_{a, n}$ is the rate of parallel retreat of the cliff, which is given by $\Delta a_{n} / \Delta t$ (the retreat direction is defined to be positive). The quantity $v_{\theta, n}$ is the rate of declining retreat of the cliff, which is given by $\Delta \theta_{n} / \Delta t$ (again, the retreat direction is positive). The quantity $B$ denotes the ratio of change from erosional volume to depositional volume (bulk density ratio) and does not vary with $n$. It is defined as:

\section{$B=\frac{\text { The volume of talus deposition }}{\text { The volume of cliff erosion }}$}

\subsection{Equations in the model}

The model involves two types of relational equation:

1) Predictive equations: these predict the slope profile (heights and inclinations of slopes) at stage $n$, based on the slope profile at stage $n-1$ and the parameters specifying topographic change $\left(v_{a, n}, v_{\theta, n}\right.$ and $\left.B\right)$.

2) Retrodictive equations: these calculate the slope profile at stage $n-1$, based on the slope profile at stage $n$ and the parameters specifying topographic change.

These two equations are shown in Appendix A (for detailed derivation of the equations, see Obanawa and Matsukura, 2006). Numerical integration by the finite difference method, using a computer, is used to find solutions of these equations.

\subsection{Modes of application}

There are two modes of model application.

1) The first mode is prediction and retrodiction of the change in talus topography (simulation). This mode provides one data set of topographic variables (the cross section data) at an arbitrary time, given the input of another data set of topographic variables and the parameters of topographic change $\left(v_{a}, v_{\theta}\right.$ and $\left.B\right)$. 
2) The second mode involves the calculation of the retreat rates of the cliff $\left(v_{a}, v_{\theta}\right)$ and the bulk density ratio $(B)$. Two data sets for the topographic variables at different times and the interval between them allow these parameters to be determined over that duration.

\section{Application of the model to talus landforms}

\subsection{Study area}

The model is applied to a talus landform in Mount St. Helens, and its topographic change is predicted. The top of the mountain collapsed during the eruption of 18 May 1980, and a caldera was formed (Fig. 3: revised after Mills, 1992, personal communication). The elevation of the top of the mountain was $2950 \mathrm{~m}$ before the eruption and $2550 \mathrm{~m}$ afterwards. The caldera, open to the north, has a diameter of about $2 \mathrm{~km}$ and a cliff height of over $600 \mathrm{~m}$. The caldera wall is composed of dacite at its deeper part (below 2100-2200m in altitude) and of andesite above that (Mills, 1992). Rockfall constitutes by far the most common form of mass wasting in the caldera; on some days thousands of rockfalls occur (Mills, 1991). Debris generated from the caldera wall is deposited at the cliff foot, so that a talus slope is formed widely. The erosional volume of the cliff, over 8years after the eruption, is $3.0 \times 10^{7} \mathrm{~m}^{3}$, and the depositional volume of the talus is $6.8 \times 10^{7} \mathrm{~m}^{3}$ (Mills, 1992). 

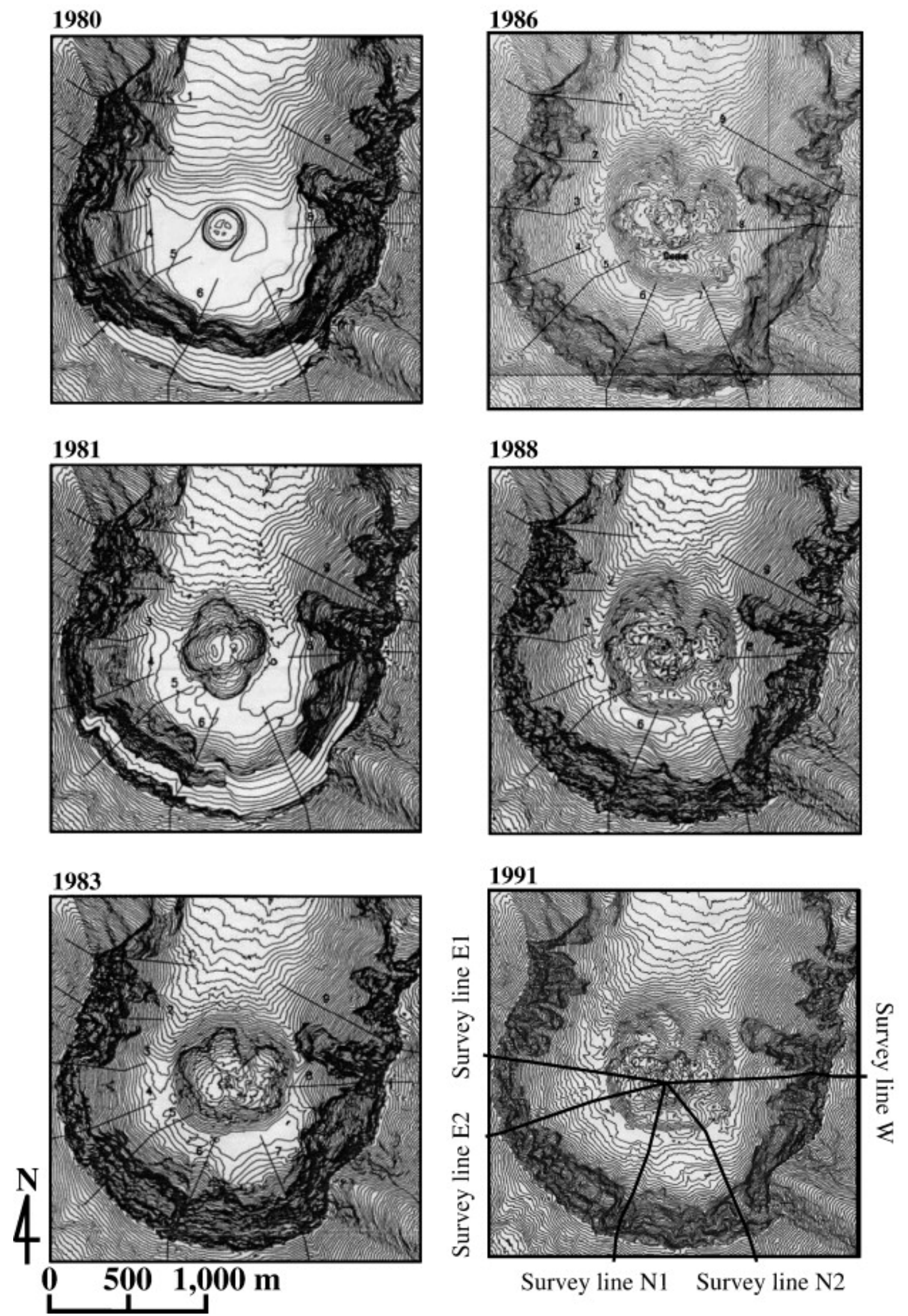
Fig. 3. Topographic change in Mount St. Helens since the 1980 eruption (after Mills, 1992 and personal communication). The contour interval is $10 \mathrm{~m}$, except for the southern part of the caldera walls in 1980 and 1981 (50 m). Nine numbered lines in the maps from 1980 to 1988 are used by Mills (1992) and are not related to the present study.

At Spirit Lake (altitude 1063m), which is located about 9km northeast of Mount St. Helens, the average annual air temperature is $5.6^{\circ} \mathrm{C}$, the average annual precipitation is $2253 \mathrm{~mm}$, and the average annual snowfall is $7.2 \mathrm{~m}$ (United States Weather Bureau, 1980). Assuming that the temperature lapse rate is $0.6^{\circ} \mathrm{C}$ per $100 \mathrm{~m}$, the average annual air temperature at the top of Mount St. Helens $(2,550 \mathrm{~m})$ is estimated to be $-3.3^{\circ} \mathrm{C}$.

\subsection{Analysis using the model}

\subsubsection{Construction of topographic profiles}

We analyzed six topographic maps of the caldera, for the years $1980,1981,1983,1986$, 1988 and 1991, having a 10m contour interval (Fig. 3). These maps show the topographic changes after the eruption. In each map, the center corresponds to the bottom of the caldera, and the round-shaped landform is the lava dome. The 1980 map indicates that the bottom of the caldera just after the eruption was relatively flat, and that the talus slopes at the foot of the caldera wall were small. Since then, the talus slopes and lava dome have gradually grown.

Five survey lines having different slope aspects were set up on the caldera walls, as shown in the 1991 map in Fig. 3. The survey line E1 is located on the east-facing caldera wall, E2 on the east-northeast-facing wall, N1 on the north-northeast-facing wall, N2 on the north-northwest-facing wall, and $\mathrm{W}$ on the west-facing wall. On each survey line the cross section of the topography at each stage was constructed using the topographic maps (Fig. 4A). In all figures the right side corresponds to the caldera wall, and the left side corresponds to the center of the caldera. The upper slopes of the caldera wall are eroded, and the lower slopes are deposited as time passes. The upheaval at the center of the caldera (left side in the figure) shows the growth of the lava dome. 


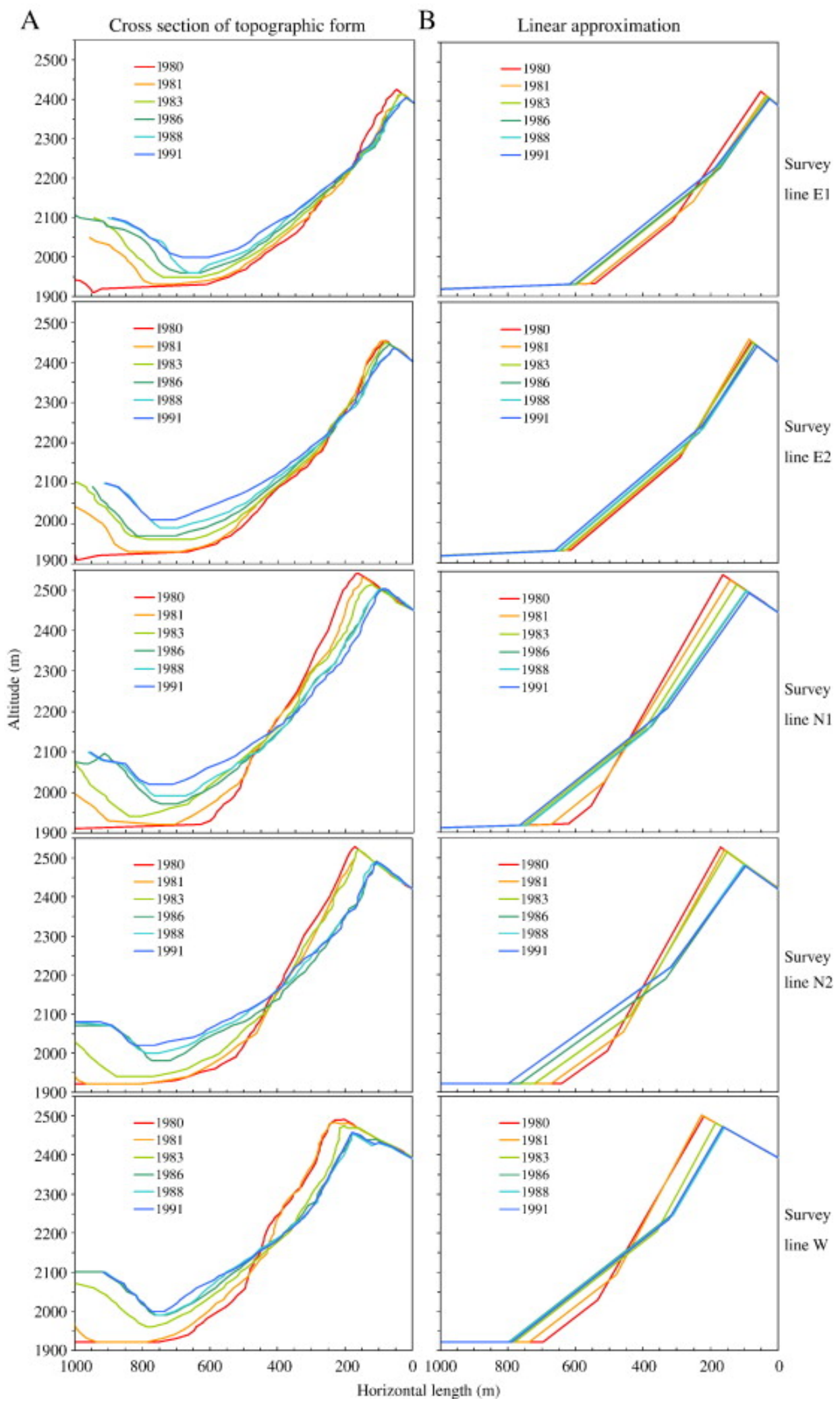

Fig. 4. Topographic cross sections of survey lines. A: actual sections; B: linear approximations. 


\subsubsection{Linear approximation of the slope form}

The topographic profiles were fitted to the four linear lines of: the upper slope, the cliff face, the talus slope and the lower slope. The slope was first divided into segments of $10 \mathrm{~m}$ in height (using the contour lines), and the slope inclinations of each segment were obtained. Since the inclination of the talus slope corresponds to the angle of repose for debris, i.e., $35^{\circ}$, a slope with inclination between $30^{\circ}$ and $40^{\circ}$ was defined to be the talus slope. Slope with inclination exceeding $40^{\circ}$ was defined as the cliff face. By applying this procedure to the entire slope, the boundary between the cliff and the talus can be determined. The mountainside slope (outer slope from the top of the caldera wall) in the cross section of the topography in 1980 was defined as the upper slope. Also, the flat slope at the bottom of the caldera in 1980 was defined as the lower slope. Each slope section classified by these procedures was fitted to straight lines by the method of least squares. Consequently, four lines were obtained corresponding to the upper slope, the cliff face, the talus slope and the lower slope.

The talus inclination is assumed to be unchanging with time in the model (see Obanawa and Matsukura, 2006). The inclinations of the talus slope were calculated at six stages for each survey line, and the averaged values (from $31.9^{\circ}$ to $35.6^{\circ}$ ) were used as the corresponding talus inclinations. Table 1 lists the calculated inclinations and heights of the slopes. The approximated topographic profiles constructed using these values are shown in Fig. 4B.

Table 1.

Temporal topographic change along five survey lines based on linear approximation of topographic segments

\begin{tabular}{|c|c|c|c|c|c|c|}
\hline \multirow[b]{2}{*}{$\begin{array}{l}\text { Shooting } \\
\text { date }\end{array}$} & \multicolumn{6}{|c|}{ Topographic map } \\
\hline & $\begin{array}{l}10 / 23 / 198 \\
0\end{array}$ & $\begin{array}{l}9 / 10 / 198 \\
1\end{array}$ & $\begin{array}{l}8 / 17 / 198 \\
3\end{array}$ & $\begin{array}{l}10 / 12 / 198 \\
6\end{array}$ & $\begin{array}{l}10 / 20 / 198 \\
8\end{array}$ & $\begin{array}{l}9 / 12 / 199 \\
1\end{array}$ \\
\hline
\end{tabular}




\begin{tabular}{|c|c|c|c|c|c|c|c|}
\hline $\begin{array}{l}\text { Surve } \\
\text { y line }\end{array}$ & $\begin{array}{l}\text { Elapsed } \\
\text { time from } \\
\text { the } \\
\text { eruption } \\
\text { (day) }\end{array}$ & 158 & 480 & 1186 & 2338 & 3077 & 4134 \\
\hline \multirow[t]{6}{*}{$\mathrm{E} 1$} & $\begin{array}{l}\text { Upper-slop } \\
\text { e angle } \\
\text { (deg.) }\end{array}$ & -34.6 & -34.6 & -34.6 & -34.6 & -34.6 & -34.6 \\
\hline & $\begin{array}{l}\text { Cliff-slope } \\
\text { angle } \\
\text { (deg.) }\end{array}$ & 51.8 & 51.7 & 51.5 & 51.4 & 49.4 & 47.9 \\
\hline & $\begin{array}{l}\text { Cliff-slope } \\
\text { height }(m)\end{array}$ & 333.1 & 270.7 & 200.1 & 181.3 & 165.1 & 179.2 \\
\hline & $\begin{array}{l}\text { Talus slope } \\
\text { angle } \\
\text { (deg.) }\end{array}$ & 34.6 & 34.6 & 34.6 & 34.6 & 34.6 & 34.6 \\
\hline & $\begin{array}{l}\text { Talus-slope } \\
\text { height }(\mathrm{m})\end{array}$ & 158.7 & 212.0 & 280.4 & 296.8 & 311.7 & 297.4 \\
\hline & $\begin{array}{l}\text { Bottom-slo } \\
\text { pe angle } \\
\text { (deg.) }\end{array}$ & 1.8 & 1.8 & 1.8 & 1.8 & 1.8 & 1.8 \\
\hline \multirow[t]{6}{*}{ E2 } & $\begin{array}{l}\text { Upper-slop } \\
\text { e angle } \\
\text { (deg.) }\end{array}$ & -32.9 & -32.9 & -32.9 & -32.9 & -32.9 & -32.9 \\
\hline & $\begin{array}{l}\text { Cliff-slope } \\
\text { angle } \\
\text { (deg.) }\end{array}$ & 54.0 & 55.5 & 52.5 & 52.8 & 51.9 & 50.3 \\
\hline & $\begin{array}{l}\text { Cliff-slope } \\
\text { height (m) }\end{array}$ & 290.9 & 279.1 & 272.2 & 218.6 & 205.0 & 200.1 \\
\hline & $\begin{array}{l}\text { Talus slope } \\
\text { angle } \\
\text { (deg.) }\end{array}$ & 35.6 & 35.6 & 35.6 & 35.6 & 35.6 & 35.6 \\
\hline & $\begin{array}{l}\text { Talus-slope } \\
\text { height }(\mathrm{m})\end{array}$ & 230.4 & 247.1 & 246.7 & 296.0 & 305.5 & 310.9 \\
\hline & $\begin{array}{l}\text { Bottom-slo } \\
\text { pe angle } \\
\text { (deg.) }\end{array}$ & 2.2 & 2.2 & 2.2 & 2.2 & 2.2 & 2.2 \\
\hline N1 & $\begin{array}{l}\text { Upper-slop } \\
\text { e angle } \\
\text { (deg.) }\end{array}$ & -29.9 & -29.9 & -29.9 & -29.9 & -29.9 & -29.9 \\
\hline
\end{tabular}




\begin{tabular}{|c|c|c|c|c|c|c|c|}
\hline & \multirow[b]{2}{*}{$\begin{array}{l}\text { Shooting } \\
\text { date }\end{array}$} & \multicolumn{6}{|c|}{ Topographic map } \\
\hline & & $\begin{array}{l}10 / 23 / 198 \\
0\end{array}$ & $\begin{array}{l}9 / 10 / 198 \\
1\end{array}$ & $\begin{array}{l}8 / 17 / 198 \\
3\end{array}$ & $\begin{array}{l}10 / 12 / 198 \\
6\end{array}$ & $\begin{array}{l}10 / 20 / 198 \\
8\end{array}$ & $\begin{array}{l}9 / 12 / 199 \\
1\end{array}$ \\
\hline \multirow[t]{6}{*}{$\begin{array}{l}\text { Surve } \\
\text { y line }\end{array}$} & $\begin{array}{l}\text { Elapsed } \\
\text { time from } \\
\text { the } \\
\text { eruption } \\
\text { (day) }\end{array}$ & 158 & 480 & 1186 & 2338 & 3077 & 4134 \\
\hline & $\begin{array}{l}\text { Cliff-slope } \\
\text { angle } \\
\text { (deg.) }\end{array}$ & 56.0 & 53.6 & 53.0 & 50.1 & 50.0 & 49.9 \\
\hline & $\begin{array}{l}\text { Cliff-slope } \\
\text { height }(m)\end{array}$ & 577.8 & 504.8 & 358.8 & 336.6 & 347.6 & 288.3 \\
\hline & $\begin{array}{l}\text { Talus slope } \\
\text { angle } \\
\text { (deg.) }\end{array}$ & 33.9 & 33.9 & 33.9 & 33.9 & 33.9 & 33.9 \\
\hline & $\begin{array}{l}\text { Talus-slope } \\
\text { height }(\mathrm{m})\end{array}$ & 44.6 & 105.7 & 243.1 & 248.1 & 238.1 & 292.7 \\
\hline & $\begin{array}{l}\text { Bottom-slo } \\
\text { pe angle } \\
\text { (deg.) }\end{array}$ & 1.5 & 1.5 & 1.5 & 1.5 & 1.5 & 1.5 \\
\hline \multirow[t]{6}{*}{$\mathrm{N} 2$} & $\begin{array}{l}\text { Upper-slop } \\
\text { e angle } \\
\text { (deg.) }\end{array}$ & -32.9 & -32.9 & -32.9 & -32.9 & -32.9 & -32.9 \\
\hline & $\begin{array}{l}\text { Cliff-slope } \\
\text { angle } \\
\text { (deg.) }\end{array}$ & 57.4 & 57.3 & 55.7 & 51.1 & 50.6 & 49.4 \\
\hline & $\begin{array}{l}\text { Cliff-slope } \\
\text { height }(m)\end{array}$ & 522.9 & 467.1 & 418.7 & 291.4 & 261.9 & 258.5 \\
\hline & $\begin{array}{l}\text { Talus slope } \\
\text { angle } \\
\text { (deg.) }\end{array}$ & 31.9 & 31.9 & 31.9 & 31.9 & 31.9 & 31.9 \\
\hline & $\begin{array}{l}\text { Talus-slope } \\
\text { height }(\mathrm{m})\end{array}$ & 85.4 & 133.0 & 176.8 & 269.5 & 300.7 & 300.7 \\
\hline & $\begin{array}{l}\text { Bottom-slo } \\
\text { pe angle } \\
\text { (deg.) }\end{array}$ & 0 & 0 & 0 & 0 & 0 & 0 \\
\hline W & Upper-slop & -25.9 & -25.9 & -25.9 & -25.9 & -25.9 & -25.9 \\
\hline
\end{tabular}




\begin{tabular}{|c|c|c|c|c|c|c|c|}
\hline & \multirow[b]{2}{*}{$\begin{array}{l}\text { Shooting } \\
\text { date }\end{array}$} & \multicolumn{6}{|c|}{ Topographic map } \\
\hline & & $\begin{array}{l}10 / 23 / 198 \\
0\end{array}$ & $\begin{array}{l}9 / 10 / 198 \\
1\end{array}$ & $\begin{array}{l}8 / 17 / 198 \\
3\end{array}$ & $\begin{array}{l}10 / 12 / 198 \\
6\end{array}$ & $\begin{array}{l}10 / 20 / 198 \\
8\end{array}$ & $\begin{array}{l}\text { 9/12/199 } \\
1\end{array}$ \\
\hline \multirow{7}{*}{$\begin{array}{l}\text { Surve } \\
\text { y line }\end{array}$} & Elapsed & 158 & 480 & 1186 & 2338 & 3077 & 4134 \\
\hline & $\begin{array}{l}\text { e angle } \\
\text { (deg.) }\end{array}$ & & & & & & \\
\hline & $\begin{array}{l}\text { Cliff-slope } \\
\text { angle } \\
\text { (deg.) }\end{array}$ & 56.2 & 58.2 & 58.0 & 56.4 & 56.1 & 56.0 \\
\hline & $\begin{array}{l}\text { Cliff-slope } \\
\text { height }(m)\end{array}$ & 471.1 & 408.8 & 277.7 & 226.8 & 224.2 & 237.7 \\
\hline & $\begin{array}{l}\text { Talus slope } \\
\text { angle } \\
\text { (deg.) }\end{array}$ & 34.0 & 34.0 & 34.0 & 34.0 & 34.0 & 34.0 \\
\hline & $\begin{array}{l}\text { Talus-slope } \\
\text { height }(\mathrm{m})\end{array}$ & 108.5 & 173.9 & 285.4 & 326.2 & 326.8 & 314.6 \\
\hline & $\begin{array}{l}\text { Bottom-slo } \\
\text { pe angle } \\
\text { (deg.) }\end{array}$ & 0 & 0 & 0 & 0 & 0 & 0 \\
\hline
\end{tabular}

\subsubsection{Calculation of the bulk density ratio}

The volume of cliff erosion during the eight years since the eruption is $3.0 \times 10^{7} \mathrm{~m}^{3}$, and the volume of talus deposition during the same period is $6.8 \times 10^{7} \mathrm{~m}^{3}$ (Mills, 1992). The $B$-value is consequently calculated to be 2.27 using Eq. (1). This value is larger than that expected from the increase in porosity when the rock mass changes into debris. Mills (1992) reported that: (1) the snow on the talus slope is covered and insulated by the rockfall from the cliff; (2) the talus sediment includes snow preserved throughout the year; and (3) the porosity of the entire talus sediment is large.

\subsubsection{Calculation of the rate of declining cliff retreat}


Fig. 5A shows the change in cliff inclination with time. Although there is some data scatter, the cliff inclinations tend to decrease with time for all survey lines. A power-law curve was fitted to each survey line (Fig. 5A) according to previous studies of the declining retreat of a cliff ([Crittenden and Muhs, 1986], [Suzuki and Nakanishi, 1990] and [Suzuki et al., 1991]). The fitted equations are:

$\mathrm{E} 1: \quad \gamma=57.8 t^{-0.0188}$

E2 $: \quad \gamma=61.4 t^{-0.0214}$

N1: $\gamma=67.8 t^{-0.0324}$

$\mathrm{N} 2: \gamma-75.9 t^{-0.0495}$

W: $\quad \gamma=58.6 t^{-0.00426}$

where $y$ is the cliff angle (in degrees) and $t$ is the number of days from the eruption.

Equations for the temporal change in the declining-retreat rate of cliff $\left(v_{\theta}\right.$; degrees day $\left.{ }^{-1}\right)$ were calculated by differentiating Eqs. (2) (3) (4) (5) (6) with respect to time:

E1 : $\quad v_{\theta}=1.09 t^{-1.0188}$

E2 : $\quad v_{\theta}=1.32 t^{-1.0214}$ 
$\mathrm{N} 2: \quad v_{0}=3.76 t^{-1.0495}$

(11)

$$
W: \quad v_{\theta}=0.249 t^{-1.00426}
$$

A

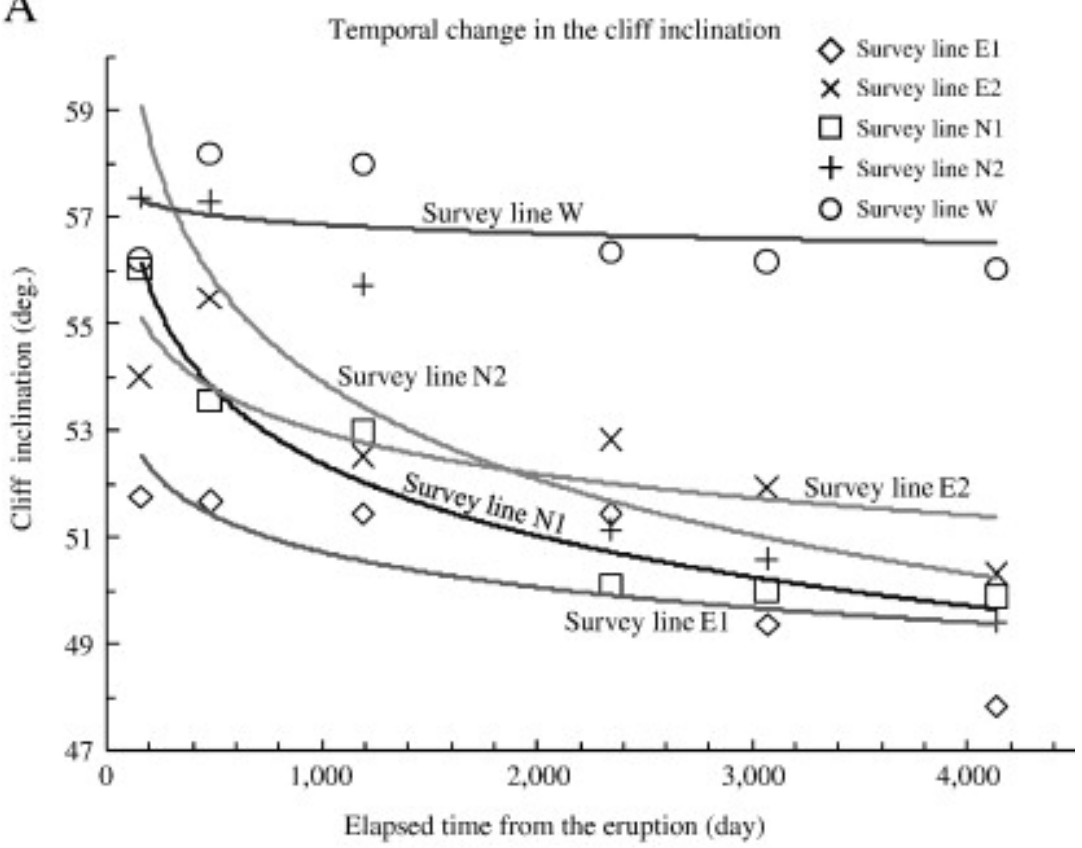

B

Temporal change in the rate of declining retreat of cliff, $v_{\theta}$

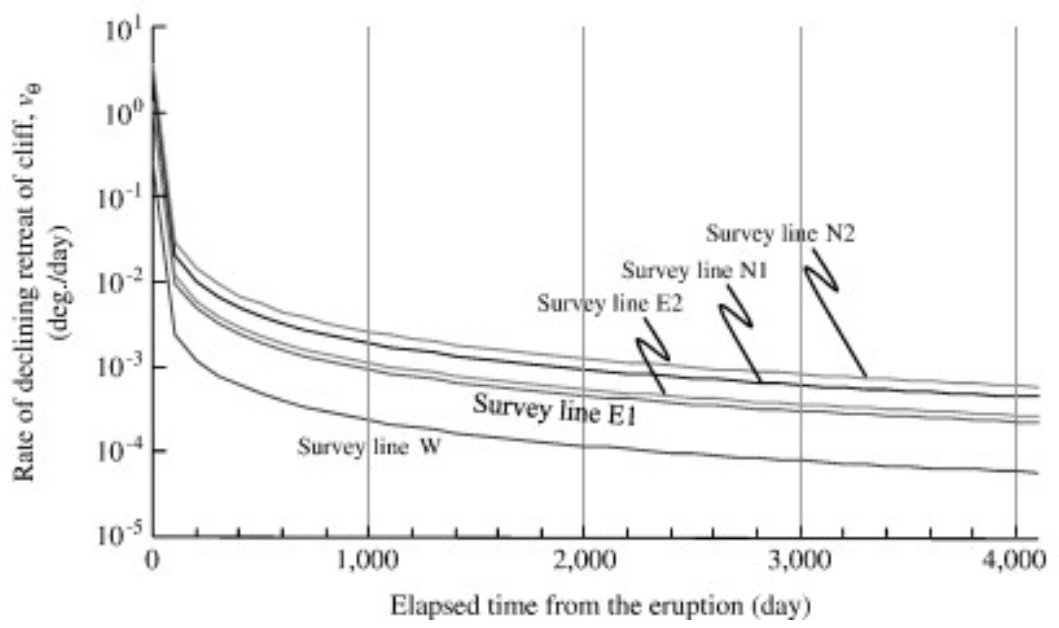

Fig. 5. Declining retreat of cliff. A: Temporal change in cliff inclination; B: Temporal change in rate of declining cliff retreat, $v_{\theta}$. 


\subsubsection{Calculation of the rate of parallel retreat of cliff}

The rate of parallel retreat of cliff, $v_{a}$, was calculated using the temporal changes of the topography (Table 1), Eqs. (7) (8) (9) (10) (11), and the value of $B$. Since topographic data exist at six times from 1980 to 1991, analyses using the model can be carried out for five intervals, namely 1980 to 1981,1981 to 1983,1983 to 1986, 1986 to 1988 and 1988 to 1991. The $v_{a}$-values were assumed to be constant during each period.

Values of $v_{a}$ can be obtained by processing these data, using the model (see Obanawa and Matsukura, 2006 for the detailed processes). The resulting $v_{a}$-values are shown in Fig. 6. The maximum value of $v_{a}$ was $33 \mathrm{~mm}$ day $^{-1}$ between 1981 and 1983 for the survey line W. This value is very large, and suggests that major topographic changes occurred on the cliff face. As shown in Fig. $6 \mathrm{~A}$, although the $v_{a}$-values show a large variation with elapsed time for each survey line, the general trend is a decrease with elapsed time. 


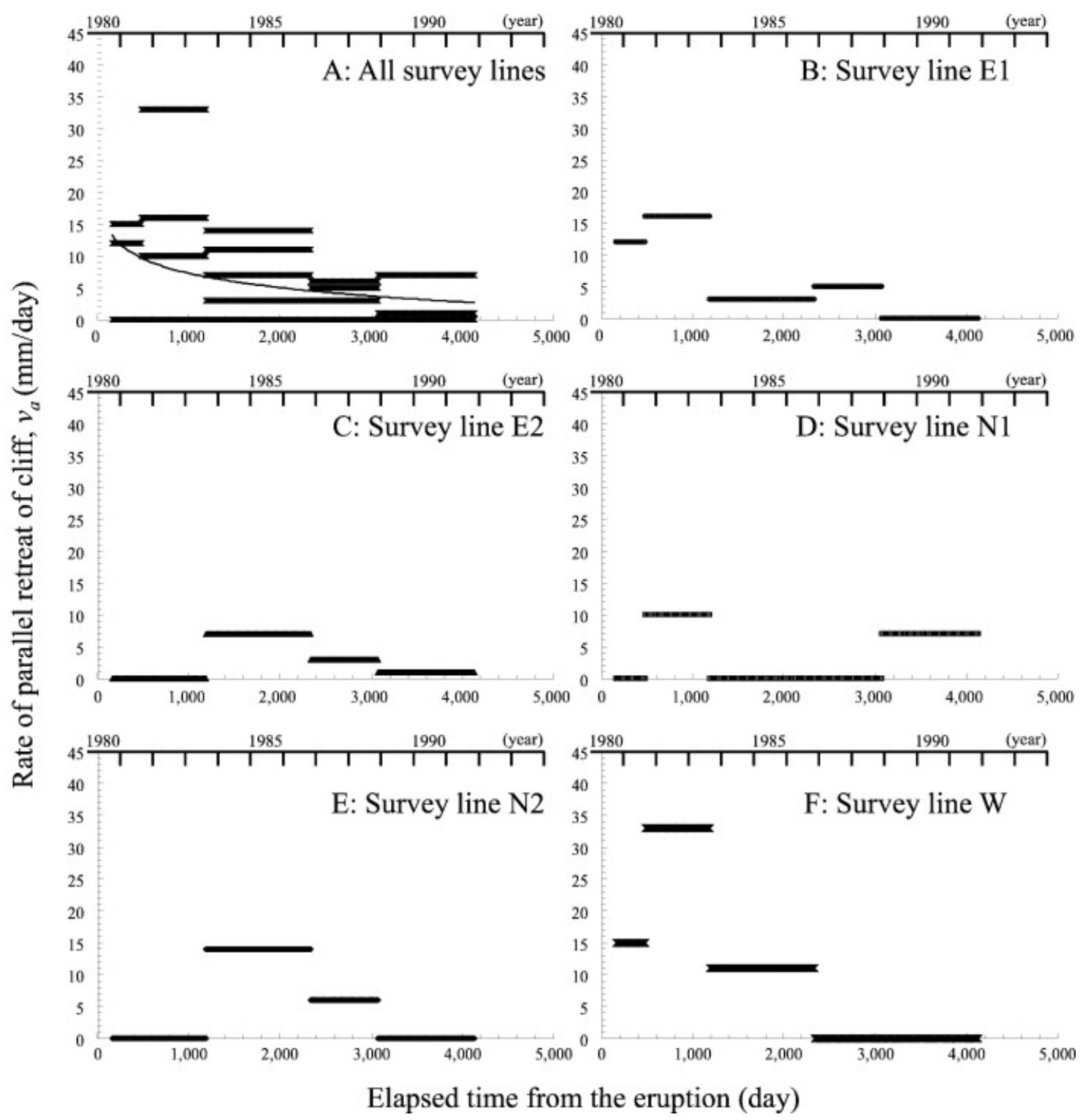

Fig. 6. Temporal change in rate of parallel cliff retreat, $v_{a}$.

\subsection{Prediction of talus development}

\subsubsection{Setting of the simulation}

Future topographic changes at the caldera wall of Mount St. Helens were predicted using the model. The topographic data in 1991, the newest topographic map, were used to define stage 0 of the model, and topographic changes were predicted by running the model. Eqs. (7) (8) (9) (10) (11) are used for the $v_{\theta}$-values. The $v_{a}$-values in Fig. 6 are used directly as a 
step function. For the period 0 to 158days during which the $v_{a}$-values are not known, the $v_{a}$-values during days 158 to 480 were used. Also, since $v_{a}$-values during days 3,077 to 4,134 are almost zero except for the survey line $N 1$, the $v_{a}$-values subsequent to 4,134 days are taken to be zero for all survey lines.

It is not clear whether the buried snow in the talus slope will melt or last in the future. Also, the temporal change in the ratio of snow to rockfall is unknown. Two distinct simulations were therefore run: 1) snow accumulation will not occur in the future, and 2) snow accumulation will continue at approximately the present rate. First, the computer program expressing the model was modified to separate the volume increase by snow accumulation from that by rockfall, so that terms specifying the volume increase of the talus by snow accumulation alone were added to the program. The annual rate of snow accumulation was then examined. The volume of snow accumulation during 1980 to 1988 is estimated to be $2.8 \times 10^{7} \mathrm{~m}^{3}$, and the area of the crater is estimated to be $3.9 \times 10^{6} \mathrm{~m}^{2}$ (Mills, 1992). The average depth of snow accumulation during eight years is therefore $\left(2.8 \times 10^{7} \mathrm{~m}^{3}\right) /$ $\left(3.9 \times 10^{6} \mathrm{~m}^{2}\right)=7.2 \mathrm{~m}$, and the mean annual depth of snow accumulation is estimated to be about $0.9 \mathrm{~m}$. Since the area of the crater includes the caldera wall, upon which it is difficult for snow to accumulate, the mean annual depth of snow accumulation on talus slopes is re-estimated to be $1.0 \mathrm{~m}$. Also, the bulk density of talus deposits when they are not affected by expansion by buried snow is assumed to be 1.33 (Mills, 1992).

The large topographic changes caused by volcanic collapse and voluminous ash falls, such as that in 1980, make simulation of talus development impossible. Consequently, the frequency of eruptive activity was surveyed on the basis of Crandell et al. (1975). Eruption events occurred nine times during 1300 to 1900A.D. The magnitude of any individual eruption is not known with certainty, but it might be quite large. The average eruption cycle is calculated to be about 65years. However, the eruption interval is not constant; there was no eruption during 1500 to 1800 . The period of calculation was therefore set at 300 years.

\subsubsection{Topographic changes}

Fig. 7 shows the simulated topographic changes of the caldera wall for each survey line. Fig. $7 \mathrm{~A}$ shows the case without snow accumulation, and Fig. 7B shows the case with snow accumulation at a rate of $1 \mathrm{~m}$ year $^{-1}$. Likewise, Fig. 8 shows temporal changes in the heights of the talus and cliff at each survey line for the two cases, including the actual changes before 1991 (as in Table 1), as obtained from topographic maps. In the case of no snow accumulation, relatively large cliff retreat and talus growth are expected after 1991 at the 
survey lines N1 and N2, whereas topographic change is predicted to be small at the survey line $\mathrm{W}$, and changes at the survey lines E1 and E2 should be intermediate. The talus slope will not reach its growth limit within 300years after the eruption. If, however, a snow accumulation of $1 \mathrm{~m}$ year $^{-1}$ is assumed, talus growth will terminate at 72 years from the eruption at the survey line E1, and after 138 years at the survey line $\mathrm{W}$, because the talus slopes will completely cover the caldera wall. 
A

No snow accumulation

B With snow accumulation
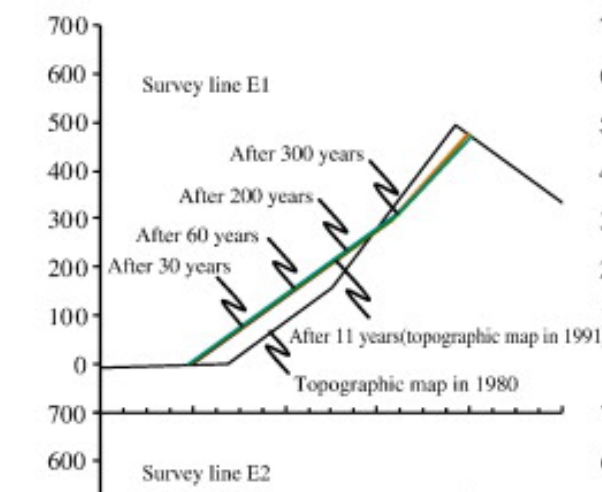

700 (1 m/year)
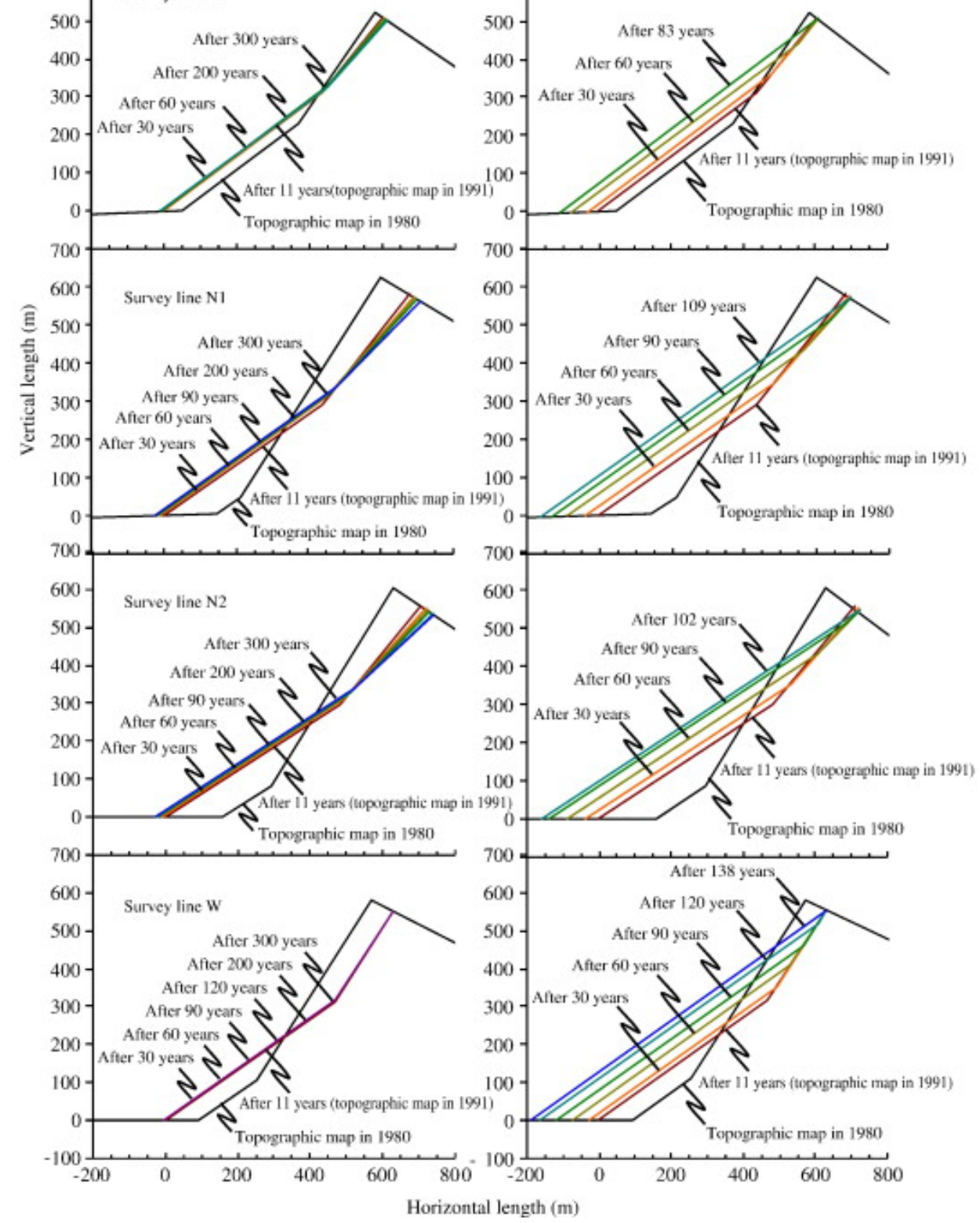

Fig. 7. Predicted talus development in Mount St. Helens. A: No snow accumulation; B: With snow accumulation (1 m/year). 


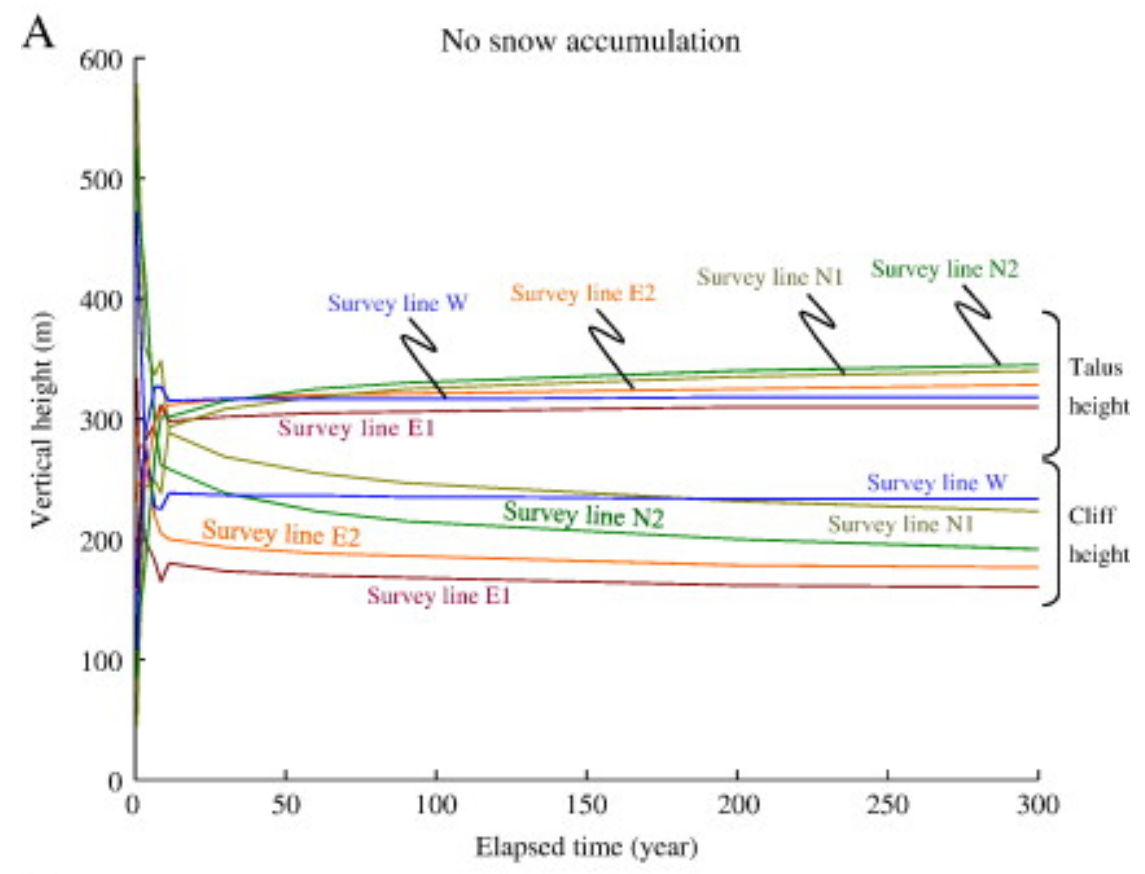

B With snow accumulation $(1 \mathrm{~m} /$ year $)$

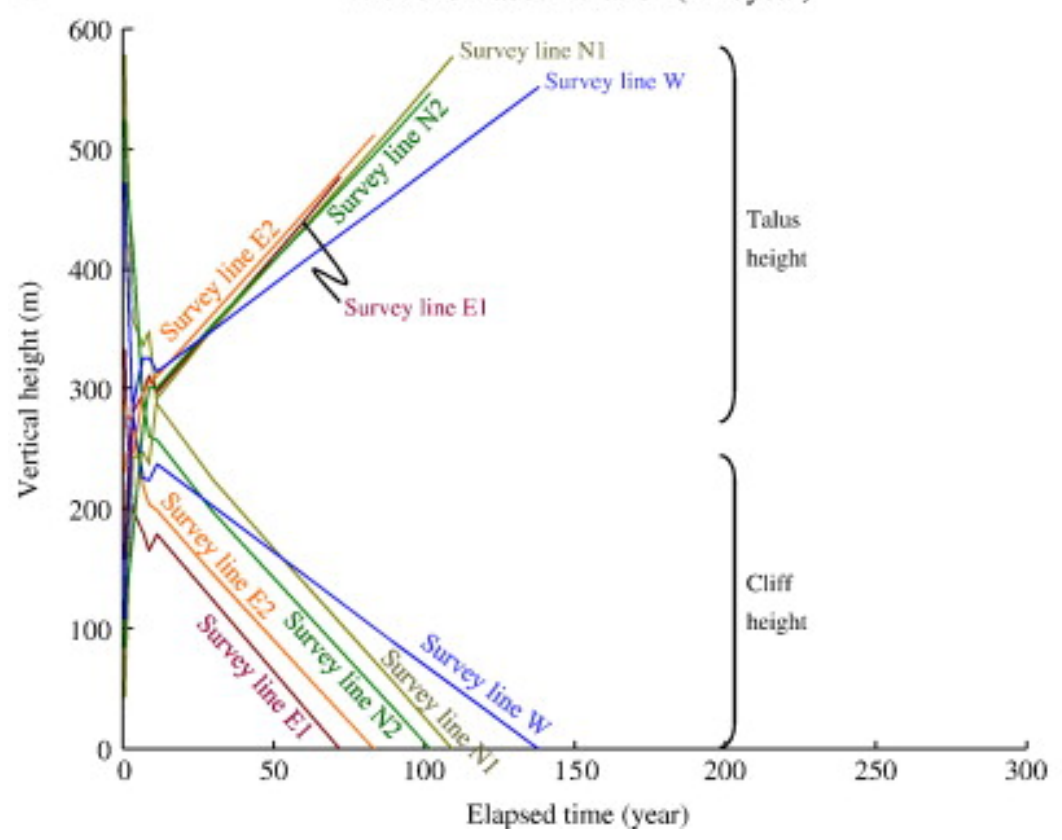

Fig. 8. Predicted temporal changes in cliff height and talus height. A: No snow accumulation; B: With snow accumulation (1 $\left.\mathrm{m}_{\text {year }}{ }^{-1}\right)$.

Fig. 9 shows the temporal changes in cliff inclination at each survey line, also including the actual changes before 1991. The inclinations are expected to decrease continuously, especially at the survey lines N1 and N2, but they become almost constant at the survey line 
W. The inclination of the survey line N2 is predicted to become about $42^{\circ}$ at $300 y$ years after the eruption, and the inclination of the survey line $W$ is predicted to become about $55^{\circ}$, although the cliffs may be completely covered with talus deposits within 300years if there is snow accumulation.

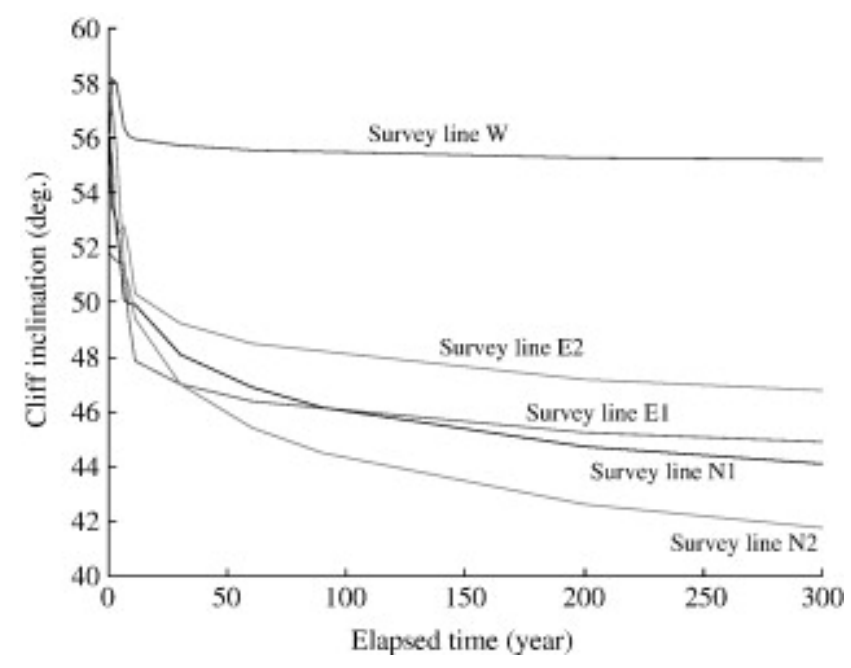

Fig. 9. Predicted temporal change in cliff inclination.

As shown in Fig. 7 and Fig. 9, the amounts of topographic changes are ranked as:

\section{north face( $(\mathrm{N} 1$ and $\mathrm{N} 2)>\operatorname{east}$ face( $\mathrm{E} 1$ and $\mathrm{E} 2)$ $>$ west face(W).}

According to Hall (2004), the ground surface temperatures of cliffs with different aspects are ranked as:

south face $>$ west face $>$ cast face $>$ north face.

The north-facing slope is therefore liable to freeze and the erosional volume by frost weathering should be large. In contrast, the west-facing slope is relatively warm, and weathering and erosion should be slower. These estimated differences are consistent with the modeling results shown in Fig. 7 and Fig. 9. The differences in topographic change between the five survey lines should therefore be caused by the differences in weathering conditions associated with slope aspect.

\subsubsection{Talus growth}


The ratio of talus height to the height of the whole slope is proposed as a measure of talus growth ("talus maturity", as defined by Ballantyne and Eckford, 1984: abbreviated to TM). Fig. 10 shows the temporal changes in TM for Mount St. Helens, based on the results of modeling. The actual changes before 1991 are also included in Fig. 10. Spike-like changes in the early stages at E1 and W are due to decreases of talus height during 1988 to 1991 (Table 1). If the snow accumulation is zero, major topographic changes occur in the first 10 years after the eruption. Thereafter, the talus slopes at N1 and N2 are expected to grow gradually, whereas talus growth at $\mathrm{W}$ should be very slow. If snow accumulation at $1 \mathrm{~m}$ year $^{-1}$ is assumed, the talus slopes are predicted to grow continuously.

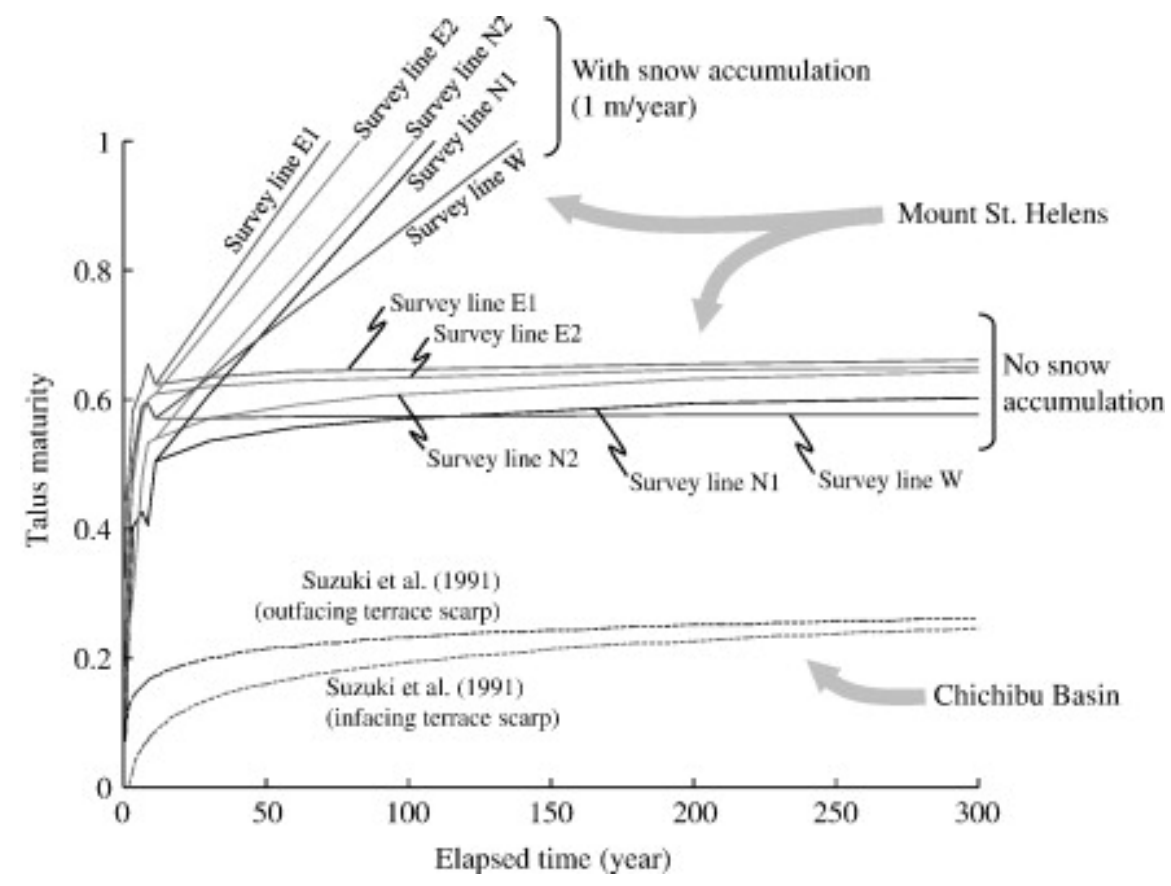

Fig. 10. Predicted temporal change in "talus maturity" (height of talus / height of whole slope) for Mount St. Helens and Chichibu Basin.

Fig. 10 also shows the TM values for the fluvial terrace scarps composed of Miocene sedimentary rocks in the Chichibu Basin, Japan, based on the data of Suzuki et al. (1991). These authors divided the fluvial terrace scarps into three segments: 1) a crestal convex slope, 2) a middle straight slope and 3) a basal concave slope. They presented equations that express the temporal changes in "height ratio" of each slope segment, i.e., the ratio of each segment of slope to the entire terrace scarp. In these data, the segment classified as the basal concave slope is regarded as the talus slope, and the "height ratio" is converted to 
TM. Suzuki et al. (1991) also presented equations expressing the temporal changes in the "height ratio" for the infacing scarp and the outfacing scarp. No snow accumulation is expected in the case of Chichibu, which has a much warmer climate.

The TM values for the Chichibu terraces and for Mount St. Helens show a similar tendency of rapid talus growth just after cliff formation, and gradual deceleration thereafter, unless snow accumulation significantly affects topographic change. However, TM for Mount St. Helens is about 0.5 to 0.7 in the case of no snow accumulation, whereas that for the Chichibu Basin is about 0.1 to 0.3 , indicating that talus growth in Mount St. Helens is much faster. This may be due to differences in the strength and/or the weathering rate of the rockwall. The caldera wall of Mount St. Helens is very unstable and yields a large amount of rockfalls.

\section{Conclusions}

We have applied a mathematical model for talus development (Obanawa and Matsukura, 2006) to topographic changes at the caldera wall of Mount St. Helens, USA during the 11 years after the volcanic eruption that formed the cliff of the caldera wall. The retreat of the cliff was evaluated, based on both the rate of declining retreat and the rate of parallel retreat. Future talus development at the caldera wall was then predicted from the model. If preserved snow accumulation in the talus deposits is assumed to be null, topographic change is large for about 10 years after the eruption and declines thereafter. The talus top will not reach the cliff top within 300 years. However, if snow accumulation in the talus deposits is assumed to be $1 \mathrm{~m}$ year $^{-1}$, the topographic change will be much larger and the caldera wall will be completely covered with talus slopes in a few hundred years. Talus growth in Mount St. Helens is much faster than in the Chichibu Basin, Japan. This may be due to the low strength and/or high weathering rate of the rockwall of Mount St. Helens, resulting in rapid production of debris and rapid retreat of the cliff.

By improving the model to consider slope forms as broken or curved lines instead of straight lines, more realistic simulation is possible. Also, as in the case of cliff retreat, the rate of snow accumulation in talus deposits may vary according to slope aspects as a result of different ground temperature, although this effect is not incorporated in the current modeling. These generalizations are for future work.

\section{Acknowledgments}


We thank Professor Hugh $\mathrm{H}$. Mills of Tennessee Technological University for providing invaluable topographic data concerning Mount St. Helens. We also express our appreciation to the editor and reviewers for helpful comments on this paper. We thank all staff of the geomorphology research group of University of Tsukuba for their useful suggestions.

\section{References}

Bakker and Le Heux, 1947 J.P. Bakker and J.W.N. Le Heux, Theory on central rectilinear recession of slopes, I. Proceedings of the Section of Sciences / Koninklijke Akademie van Wetenschappen te Amsterdam 50 (1947), pp. 959-966.

Ballantyne and Eckford, 1984 C.K. Ballantyne and J.D. Eckford, Characteristics and evolution of two relict talus slopes in Scotland, Scottish Geographical Magazine 100 (1984), pp. 20-33.

Bertran and Texier, 1999 P. Bertran and J.-P. Texier, Sedimentation processes and facies on a semi-vegetated talus, Lousteau, southwestern France, Earth Surface Processes and Landforms 24 (1999), pp. 177-187.

Caine, 1969 N. Caine, A model for alpine talus slope development by slush avalanching, Journal of Geology 77 (1969), pp. 92-100.

Carson, 1977 M.A. Carson, Angles of repose, angles of shearing resistance and angles of talus slopes, Earth Surface Processes 2 (1977), pp. 363-380.

Chandler, 1973 R.J. Chandler, The inclination of talus, arctic talus terraces, and other slopes composed of granular materials, Journal of Geology 81 (1973), pp. 1-14.

Crandell et al., 1975 D.R. Crandell, D.R. Mullineaux and M. Rubin, Mount St. Helens volcano: recent and future behavior, Science 187 (1975), pp. 438-441.

Crittenden and Muhs, 1986 R. Crittenden and D.R. Muhs, Cliff-height and slope-angle relationships in a chronosequence of Quaternary marine terraces, San Clement Island, California, Zeitschrift für Geomorphologie, Neue Folge 30 (1986), pp. 291-301.

Curry and Morris, 2004 A.M. Curry and C.J. Morris, Lateglacial and Holocene talus slope development and rockwall retreat on Mynydd Du, UK, Geomorphology 58 (2004), pp. 85-106.

Decaulne and Saemundsson, 2006 A. Decaulne and T. Saemundsson, Geomorphic evidence for present-day snow-avalanche and debris-flow impact in the Icelandic Westfjords, Geomorphology 80 (2006), pp. 80-93.

Hall, 2004 K. Hall, Evidence for freeze-thaw events and their implications for rock weathering in northern Canada, Earth Surface Processes and Landforms 29 (2004), pp. 43-57. 
Hétu and Gray, 2000 B. Hétu and J.T. Gray, Effects of environmental change on scree slope development throughout the postglacial period in the Chic-Choc Mountains in the northern Gaspé Peninsula, Québec, Geomorphology 32 (2000), pp. 335-355.

Hutchinson, 1998 J.N. Hutchinson, A small-scale field check on the Fisher-Lehmann and Bakker-Le Heux cliff degradation models, Earth Surface Processes and Landforms 23 (1998), pp. 913-926.

Hutchinson and Stuart, 2003 J.N. Hutchinson and J.T. Stuart, Analyses of the morphological changes with time, through denudation and siltation, in ditches of trapezoidal and triangular section, Journal of Archaeological Science 30 (2003), pp. 797-808.

Kirkby and Statham, 1975 M.J. Kirkby and I. Statham, Surface stone movement and scree formation, Journal of Geology 83 (1975), pp. 349-362.

Kotarba, 1997 A. Kotarba, Formation of high-mountain talus slopes related to debris-flow activity in the high Tatra Mountains, Permafrost and Periglacial Processes 8 (1997), pp. 191-204.

Lehmann, 1933 O. Lehmann, Morphologische theorie der verwitterung von steinschlagwänden, Vierteljahrsschrift der Naturforschenden Gesellschaft in Zürich 78 (1933), pp. 83-126.

Mills, 1991 H.H. Mills, Temporal variation of mass-wasting activity in Mount St. Helens crater, Washington, U.S.A. indicated by seismic activity, Arctic and Alpine Research 23 (1991), pp. 417-423.

Mills, 1992 H.H. Mills, Post-eruption erosion and deposition in the 1980 crater of Mount St Helens, Washington, determined from digital maps, Earth Surface Processes and Landforms 17 (1992), pp. 739-754.

Obanawa and Matsukura, $2006 \mathrm{H}$. Obanawa and Y. Matsukura, Mathematical modeling of talus development, Computers \& Geosciences 32 (2006), pp. 1461-1478.

Onda and Matsukura, $1997 \mathrm{Y}$. Onda and Y. Matsukura, Mechanism for the instability of slopes composed of granular materials, Earth Surface Processes and Landforms 22 (1997), pp. 401-411.

Pérez, 1988 F.L. Pérez, The movement of debris on a high Andean talus, Zeitschrift für Geomorphologie, Neue Folge 32 (1988), pp. 77-99.

Pérez, 1993 F.L. Pérez, Talus movement in the high equatorial Andes: a synthesis of ten years of data, Permafrost and Periglacial Processes 4 (1993), pp. 199-215.

Sass and Krautblatter, 2007 O. Sass and M. Krautblatter, Debris flow-dominated and rockfall-dominated talus slopes: Genetic models derived from GPR measurements, Geomorphology 86 (2007), pp. 176-192. 
Sass and Wollny, 2001 O. Sass and K. Wollny, Investigations regarding alpine talus slopes using ground-penetrating radar (GPR) in the Bavarian Alps, Germany, Earth Surface Processes and Landforms 26 (2001), pp. 1071-1086.

Scheidegger, 1961 A.E. Scheidegger, Mathematical models of slope development, Geological Society of America Bulletin 72 (1961), pp. 37-50.

Scheidegger, 1962 A.E. Scheidegger, Some modifications of the slope development problem, Geophysical Journal of the Royal Astronomical Society 7 (1962), pp. 40-53.

Statham, 1976 I. Statham, A scree slope rockfall model, Earth Surface Processes 1 (1976), pp. 43-62.

Suzuki and Nakanishi, 1990 T. Suzuki and A. Nakanishi, Rates of decline of fluvial terrace scarps in the Chichibu basin, Japan, Transactions, Japanese Geomorphological Union 11 (1990), pp. 117-149.

Suzuki et al., 1991 T. Suzuki, A. Nakanishi and T. Tsurukai, A quantitative empirical model of slope evolution through geologic time, inferred from changes in height-ratios and angles of segments of fluvial terrace scarps in the Chichibu basin, Japan, Transactions, Japanese Geomorphological Union 12 (1991), pp. 319-334.

United States Weather Bureau, 1980 United States Weather Bureau, Climatological data annual summary, Washington 1979, National Climatic Center, Ashville, N. C (1980) 19p.

\section{Appendix A. Equations of the model}

Subscripts $x$ and $y$ are Cartesian coordinates referring to the horizontal direction and the vertical direction, respectively.

1. Equations of the predictive model

$$
C_{u r-\mathbb{E}}=T_{n-1 . X}+\Delta a_{n} \frac{\tan \left(\gamma_{y-1}-\Delta \theta_{n}\right)}{\tan \left(\gamma_{n-1}-\Delta \theta_{n k}\right)-\tan \xi^{k}}
$$

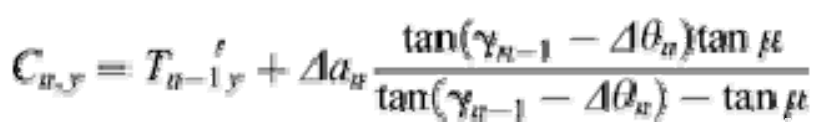




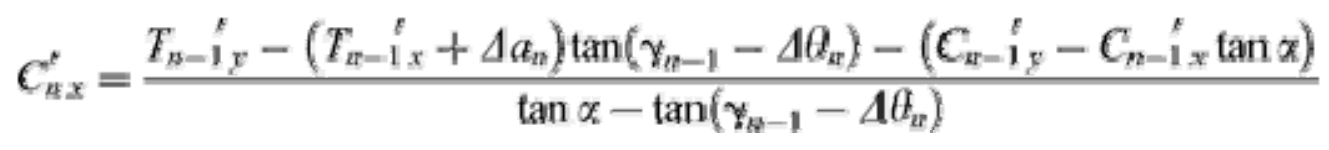

(A.4)

$$
\mathrm{C}_{n y}^{\prime}=\mathrm{C}_{n-1 y}^{\prime}+\left(\mathrm{C}_{n x}^{\prime}-\mathrm{C}_{n-1 x}^{\prime}\right) \tan *
$$

$$
T_{u_{p, *}}=\frac{-A_{2}-\sqrt{A_{2}^{2}-4 A_{1} A_{3}}}{2 A_{1}}
$$

where $A_{1}, A_{2}$ and $A_{3}$ are expressed as:

$$
A_{1}=\frac{\left\{\tan \beta-\tan \left(\gamma_{k \gamma-1}-\Delta \theta_{k}\right)\right\}(\tan \beta-\tan \beta)}{\tan \left(\gamma_{k-1}-\Delta \theta_{k}\right)-\tan \beta \varepsilon}
$$

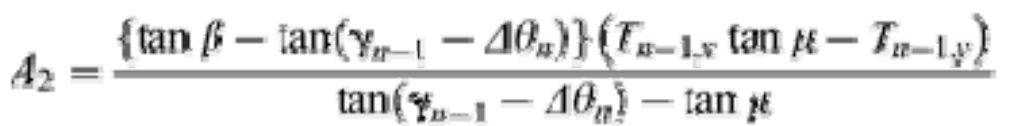

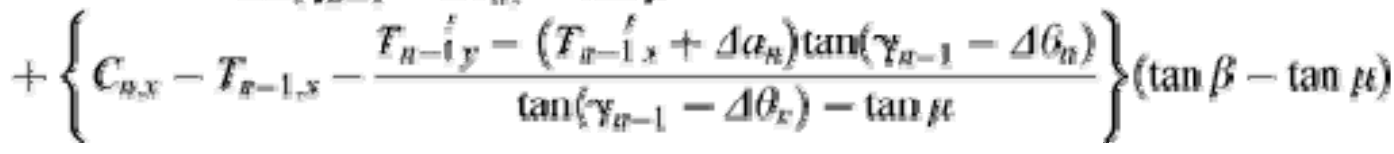

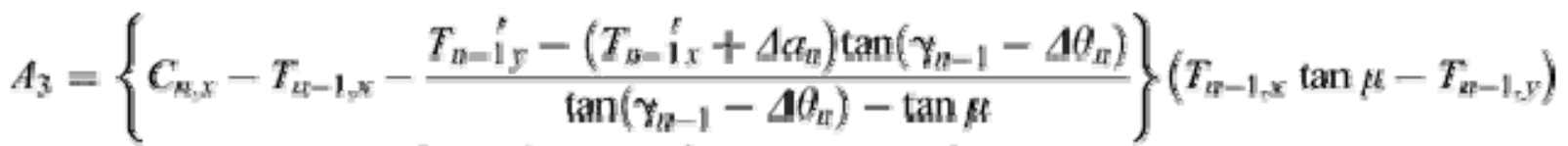

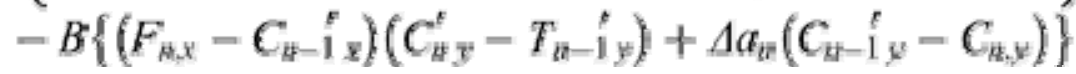

$$
T_{n, y}=T_{n, x} \tan \beta
$$




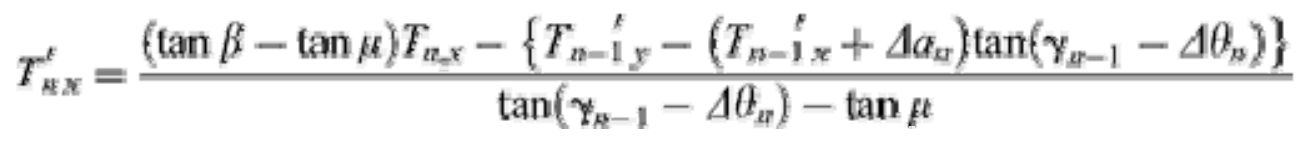

$$
\mathrm{T}_{n y}^{\prime}=T_{n, y}+\left(\mathrm{T}_{n x}^{\prime}-T_{n, x}\right) \tan \mu
$$

2. Equations of the retrodictive model

$$
T_{u-1, \varepsilon}=\frac{-A_{5}+\sqrt{A_{5}^{2}-4 A_{4} A_{6}}}{2 A_{4}}
$$

where $A_{4}, A_{5}$ and $A_{6}$ are expressed as:

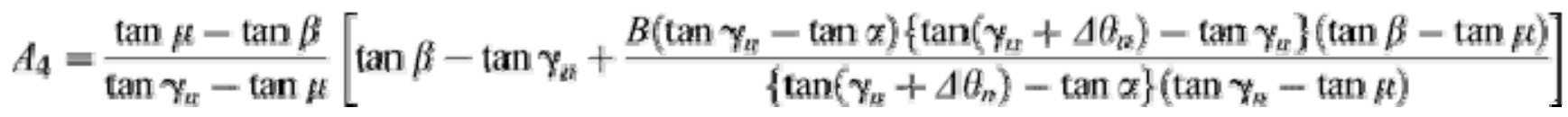

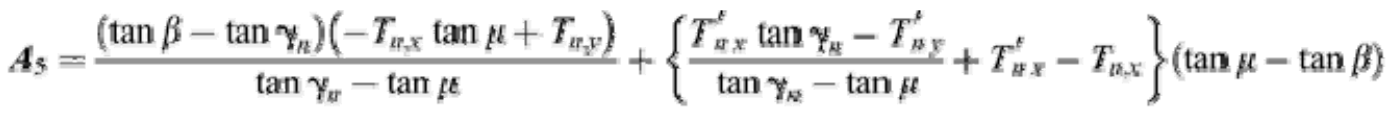

$$
\begin{aligned}
& -\frac{B}{\left\{\tan \left(\gamma_{k s}+\Delta \theta_{m}\right)-\tan \alpha\right\}\left(\tan \gamma_{*}-\tan \mu t\right)}
\end{aligned}
$$

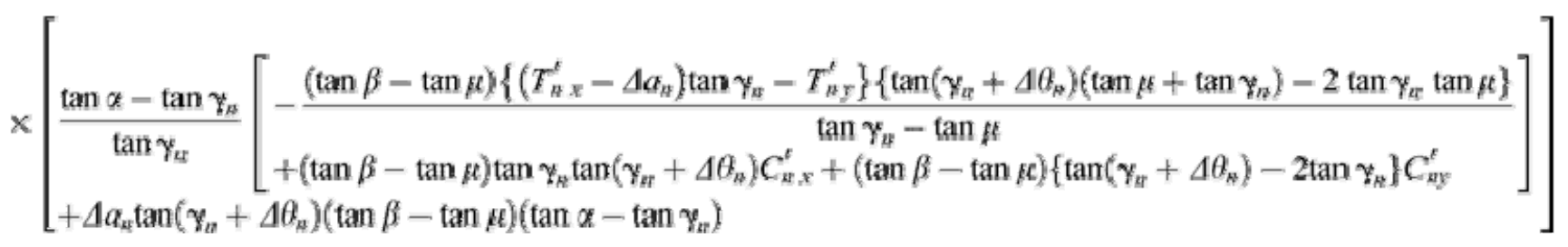




$$
\begin{aligned}
& A_{6}=\left\{\frac{T_{p x}^{s} \tan \gamma_{z}-T_{n y}^{s}}{\tan \gamma_{n}-\tan \beta t}+T_{p x}^{*}-T_{n, X}\right\}\left(-T_{n, x}^{s} \tan \beta+T_{B, y}\right)
\end{aligned}
$$

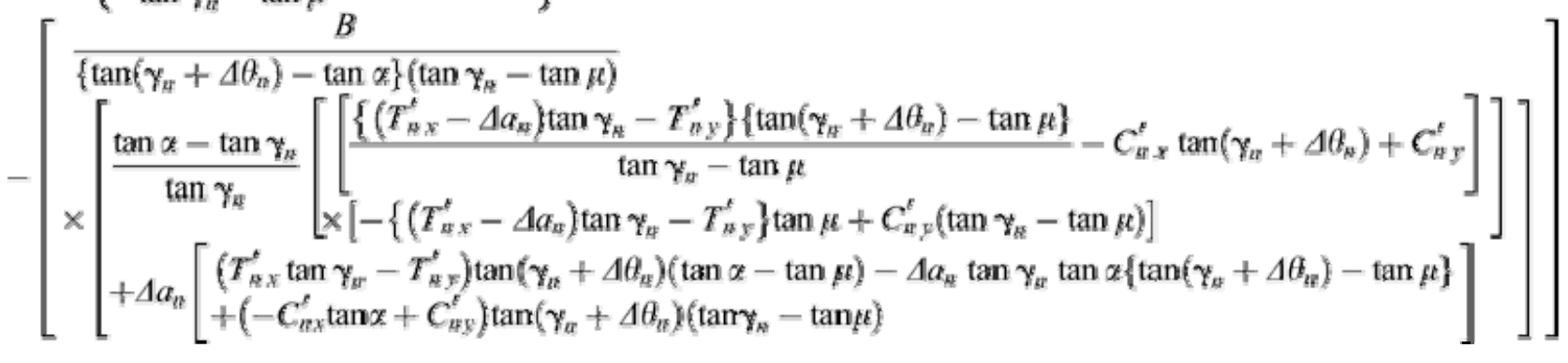

$$
T_{n-1, y}=T_{n-1, x} \tan \beta
$$

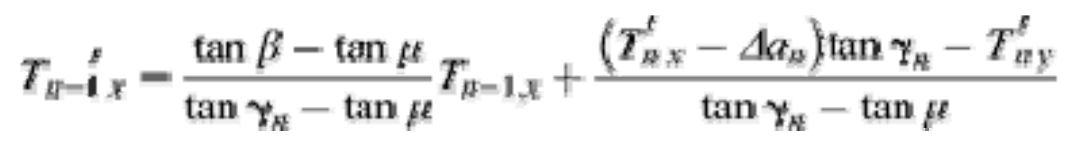

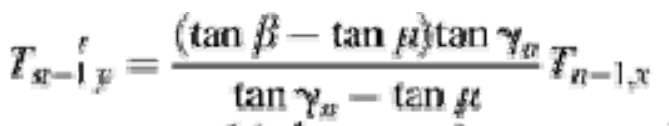

$$
\begin{aligned}
& +\frac{\left\{\left(T_{n s}^{*}-\Delta \alpha_{n}\right) \tan \gamma_{n}-T_{n y}^{z}\right\} \tan \mu}{\tan \gamma_{n}-\tan \xi}
\end{aligned}
$$

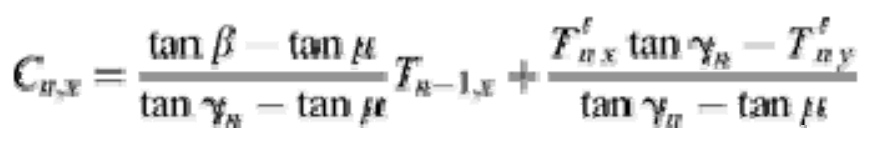

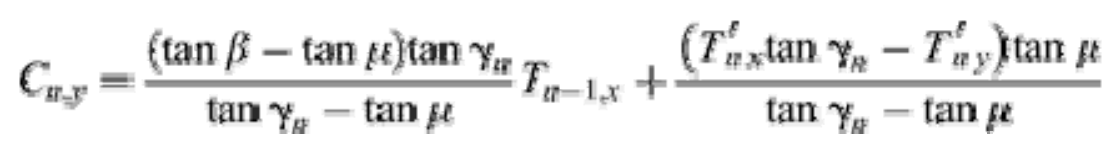




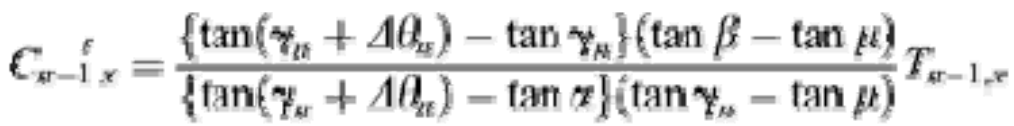

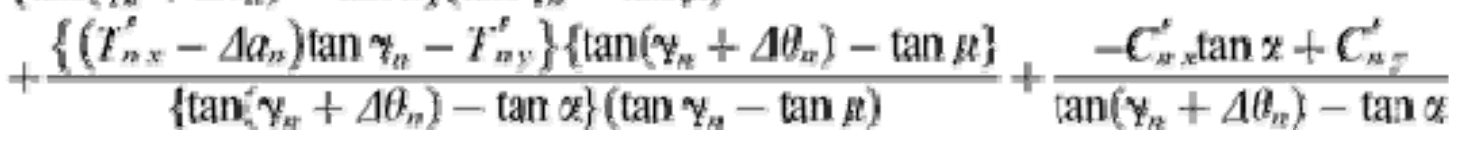

(A.22)

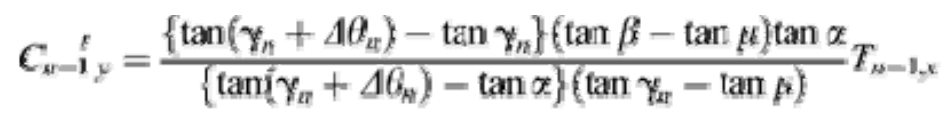

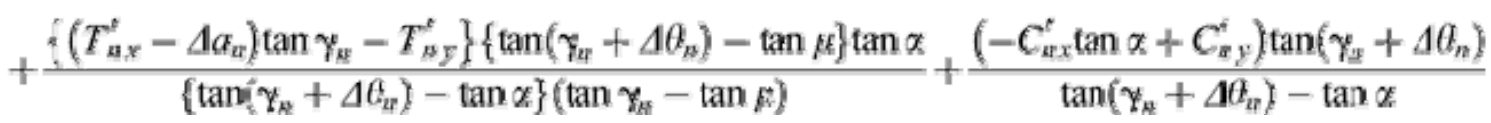

